\title{
INVESTIGATING TEACHER DISCOURSE: EXTERNAL AIDS TO INTERNAL PERSPECTIVES
}

Adriana de Carvalho Kuerten DELLAGNELO

UFSC

\begin{abstract}
The present study seeks to investigate the kind of knowledge that most has influenced four teacher-trainees' teaching. In order to pursue the purpose of this study, representations of reality - with its focus on roles ascribed to trainees and to their students - and social relations - with its focus on the discussion of foreign language teaching principles - are examined in the light of critical discourse analysis (FAIRCLOUGH, 1992) and systemic-functional grammar (HALLIDAY, 1994). The findings obtained in the analysis of ideational and interpersonal meanings indicate that the trainees, to a higher or lesser extent, picture themselves as more powerful and dominant social participants, whose roles are more active and central to the ongoing development of the lessons. When approaching foreign language teaching principles, the trainees present incoherence in reporting to hold beliefs that their discursive practices fail to corroborate. However difficult it may be to draw a clear-cut distinction between theoretical and experiential knowledge, the interpretations raised corroborate the literature in teacher education (BAILEY et al, 1996; FREEMAN, 1996a; FREEMAN, 1996b; FREEMAN; JOHNSON, 1998; FLOWERDEW, 1998) by suggesting that novice teachers tend to be influenced by experiential knowledge to a greater extent, also reiterating the contention that discourse is not only shaped by but also shapes social action (FAIRCLOUGH, 1992).
\end{abstract}

The process of formal teaching is a complex of cognitive and social activities involving the orchestration of different practices within the same superordinate social practice: the classroom. As socially constructed agents of a given culture, teachers act and behave according to the way they interpret, understand and perceive the 'reality' of the classroom. Their actions and behaviors, in turn, reflect their systems of knowledge and belief. 
Within the scope of foreign language teaching and learning, research indicates that the 'culture of teaching', which is constituted by values and beliefs teachers have regarding the content and the process of teaching/learning as well as by their perception of the institutions for which they work and their roles within them, derives from several input sources, such as: i) teachers' own experience as language learners, ii) the results of their own experience as teachers, iii) the established practice within the institution where they work, or have already worked, iv) personality factors, and v) principles derived from approaches or methods (KINDSVATTER; WILLEN; ISHLER, 1988 in RICHARDS; LOCKART, 1996).

However, prior experience, which was neglected until recently, nowadays is acknowledged as an important asset in the process of becoming a teacher. To date, scholars (FREEMAN; JOHNSON, 1998; GOLOMBEK, 1998; FLOWERDEW, 1998; VANPATTEN, 1997; BAILEY et al, 1996; FREEMAN, 1996a e 1996b) recognize the power that practicing teachers' own learning experience implicitly exerts on the future of these apprentices as teachers. In spite of all possible weaknesses in teacher education, when one becomes a teacher, s/he has already gone through thousands of hours of learning, as pointed out by Bailey et al (1996). This "apprenticeship of observation" makes her/him internalize models and behaviors of teaching that are activated as $\mathrm{s} /$ he enters a classroom. The authors argue that this may be one of the reasons why after so many efforts for change in teaching, it still remains so constant. Our educational system still tends to privilege and legitimate inequalities by reproducing a hierarchical model which emphasizes the transmission of knowledge centered in the figure of the teacher as the one who holds this knowledge.

Drawing on the interdisciplinarity of language teacher education and critical discourse analysis, the present study seeks to investigate the kind of knowledge that teachers demonstrate to rely on as they evaluate their practice. In order to accomplish this investigation, I analyze how teacher-learners represent their understanding of the process of teaching/learning a foreign language in relation to their roles and the roles of their students, and to how they position themselves and construe their identities in their discursive practices when discussing FL teaching principles. 
The data for this study are 32 self-evaluative written reports - reports of lessons teacher-trainees themselves taught - produced along one academic semester (from March 1999 to July 1999) by four ${ }^{1}$ teacher-trainees ${ }^{2}$ from "Curso de Letras" at Universidade Federal de Santa Catarina (UFSC), as an obligatory assignment for the Teaching Practicum course. The reports used in this study, thus, were not produced for the sake of research, but rather were built out of naturally occurring classroom events.

Within this perspective, this study finds support in the theory of critical discourse analysis proposed by Fairclough (1992), which, in turn, is grounded in Vygotskyan (1934/1987) understanding of construction of knowledge as social practice and as a process mediated through language. Given the importance of language in this theory, the present study has language as its object of study, drawing on Halliday's systemic functional grammar (1985/1994). Precisely, the texts are investigated from the ideational and the interpersonal perspectives.

Regarding the ideational perspective, an analysis of the lexicogrammatical system of transitivity is carried out in order to examine the roles and relations the subjects depict for themselves and for the students. At this dimension, analysis looks at the clause as an arrangement of process types, realized by verbal groups, which center on what "goings on" are portrayed in the clause; and main participants of the processes, realized by nominal groups, that are the entities evoked in the process. The transitivity analysis aims at assessing whether particular process types or participants are favored in the texts. Although this particular analysis does not investigate interpersonal meanings, based on the analysis of roles, the study attempts to establish how the social participants depict the relationship between them and the students.

As far as process types are concerned, based on Halliday's systemic functional grammar, Martin et al (1997) distinguish three fields of experience in language within the transitivity system: the field of doings and happenings (material processes), the field of consciousness, represented both internally (mental processes) and externally (verbal

\footnotetext{
${ }^{1}$ For ethical reasons, the identities of the teacher-trainees are kept secret. In this study, they are referred to as Alice, Bento, Carlos and Daniel.

${ }^{2}$ None of them had previous teaching experience before starting their Teaching Practicum course.
} 
processes), and the field of being and having (relational processes). I then focus on these four process types, whose main participants are, respectively, named Actor, Senser, Sayer and Carrier.

The investigation of interpersonal meanings aims at identifying comments related to methods, approaches, principles and techniques to foreign language teaching (ELLIS, 1997; UR, 1996; RICHARDS; LOCKART, 1994; LARSEN-FREEMAN, 1986; RICHARDS; RODGERS, 1986; KRASHEN, 1982). In order to do so, I examine lexical items related to interaction. Bearing in mind that texts are usually linguistically heterogeneous (BAKHTIN, 1981; FAIRCLOUGH, 1992, 1989), having sometimes contradictory semantic structures (monoglossia vs. heteroglossia), at this point, I examine whether there is incoherence, in terms of their reported teaching principles, between what the trainees say and how they say. As a means of picturing whether there are differences between the 'whats' and the 'hows', I investigate interpersonal meanings by examining the choices the trainees make in terms of vocabulary and of the degree of personal commitment (modality) they express to have with their propositions (HALLIDAY, 1985/1994).

Linguistic items used in texts are not arbitrarily chosen. They indicate the world-view that the writer/speaker holds. Linguistic choices may be even unconscious, but not arbitrary in the sense that behind one's use of language lie one's values and beliefs. Regarding vocabulary, as Clark (1992, p. 209) suggests, "naming is a powerful ideological tool. It is also an accurate pointer to the ideology of the namer." Different names for a similar aspect of reality thus indicate different ways of perceiving it.

Modality is an expression of the writer/speaker's opinion, while manifesting attitudes, judgments and commitment to the truth of the meanings being conveyed through her/his texts. According to systemic functional grammar, propositions are not always 100\% affirmed or denied. Between these two poles are intermediate possibilities of choice in terms of degree of probability or of usuality.

Finally, addressing the ideational and the interpersonal meanings uncovered in the previous analyses, I look at the results achieved in terms of processes and main participants most favored in the trainees' texts as well as in reference to incoherence between the 'whats' and 
'hows' of their reported teaching principles. It is assumed in this study that the 'whats' will inform the trainees' theoretical knowledge, which is here interpreted as being what they have explicitly and formally learned in their "Curso de Letras"; while the 'hows' will inform their experiential knowledge, ${ }^{3}$ which is here understood as being what students have implicitly internalized regarding the process of teaching/learning throughout their life as learners.

In reading the trainees' reports, I could notice that their intention was to adopt a communicative approach to their teaching. Communicative approaches to foreign language teaching are characterized by handling the four skills of a language - speaking, listening, reading and writing. However, they center around communicative competence developed by topic-driven syllabuses, whose aims are mainly to present relevant topics that extend students' oral and grammatical skills, to provide students with opportunities to carry out communicative tasks that require exchange of information and negotiation of meaning in pairs and groups (LARSENFREEMAN, 1986; RICHARDS; RODGERS, 1986). Needless to say, in an approach which places so much emphasis on student interaction, the role of the students is of vital importance and the teacher's is to provide the opportunities for communication, and then guide and direct learning experiences.

As to the analyses carried out, they form the basis for the discussion of theoretical and experiential knowledge in shaping teachers' practice. Suffice it to say here that although the trainees attempted to use communicative methodologies, their reports do not give evidence that they succeed in following the principles of such methodologies, at least those addressed in this study or in learner-centered lessons. The lessons were communicative-driven, but with some deviances in relation to the application of communicative principles.

In investigating ideational meanings, with a focus on the roles that the trainees depict for themselves and for their students in relation to acting (material processes), sensing (mental processes), saying (verbal processes) and being (relational processes), the findings of the transitivity

\footnotetext{
${ }^{3}$ Experiential knowledge can result from theoretical knowledge, prior experience or both.
} 
analysis reveal the trainees as somewhat alike. Overall, the subjects' discourse displays far more material processes (acting), followed by mental (sensing), verbal (saying) and relational (being), suggesting that they are more worried about reporting on actions and doings. The trainees are most often represented as the main participant of the actions, sensings, sayings and beings reported, i.e., they - not the students - are the ones who mostly act, sense, say and be.

In the next paragraphs, I approach each trainee individually and discuss their selection of social participants' roles with a focus on the kind of knowledge (theoretical and experiential) they typically draw on in their teaching.

Alice, in terms of representations of realities, appears to be largely guided by her own experiential knowledge as a learner, since theory does not support her sayings. She can be described as a transmission teacher who tries to keep control of the lesson by setting a particular interactional pattern in which she explains the subject matter, as in ... dei continuidade à explicação conforme o procedimento da aula, asks questions to check the learners' understanding, as in Terminado os ajustes iniciais da aula, distribui aos alunos a atividade 4, quando perguntei a eles o que era para ser feito nesta atividade, and makes them copy contents she writes on the board, as in ... a cada sentença que eu escrevia pedia que os alunos copiassem ao invés de terminar toda a explicaşão primeiro e só depois pedir que eles copiassem. In so doing, she ignores the interactional dynamics of the foreign language teaching/learning process, a vital strategy for communication to take place.

Another extract that seems to demonstrate that experiential knowledge is guiding Alice's practice is when she displays an authoritarian stance with students in order to have her power back and to regain control over the group, as in

Estava um pouco confuso a ordem do quadro e os alunos aproveitaram a oportunidade para reclamar quando exigi a eles que copiassem aquelas informações. Entretanto, ao caminhar pela sala, observei que apesar de um pouco confuso dava para entender tudo que estava no quadro, então determinei que todos copiassem. Os alunos estavam bastante agitados neste dia, e alguns ainda ofereceram resistência, mas, ao final, todos copiaram as informaçôes do quadro. 
The prevailing theory today in relation to power and control points out the fact that the affective filter of the students has an impact on their attitudes towards both the teacher and learning (KRASHEN, 1982). Teachers are no longer encouraged to behave in ways that raise the feeling of social distance between them and the students.

Just like Alice, Bento's behavior is not supported by the literature in terms of effective teaching/learning. It seems then, that the knowledge he brings to the classroom is mostly grounded on his prior experience as a learner. He pictures himself as unable to achieve a collaborative relationship with his learners, especially, it seems, for his unwillingness to give up the traditionally dominant role of the teacher. It is likely that his implicit model of education empowers the teacher as one who has knowledge, and the learners as ones who do not, and their reason to be in class is to learn what the teacher knows. The teacher's role then is not only to control the flow of events in class, but also to control the students, their actions, behavior and so forth, as can be noticed in ...pedi a um aluno que explicasse à turma o conteúdo da prova. Este mesmo aluno estava bastante agitado ao adentrar a sala, pedi para que sentasse na primeira carteira da sala, para que pudesse tê-lo sob maior controle. The students' role, in turn, is to do what the teacher tells them to do so that they can succeed in their learning, as in Nos minutos finais da aula, fir. com os alunos uma revisão do conteúdo que seria pedido na prova, lembrando-os que para estudar para a mesma deveriam refazer as atividades trabalhadas em sala. The low number of verbal processes produced by this trainee shows that he does not give interaction its due importance, at least from the perspective of his reported practice. He and the students say little, suggesting a passive setting from a verbal point of view, where neither the teacher nor the students discuss, argue or debate. Not even the traditional asking, answering and reacting interactional pattern is present is this trainee's reported practice, signaling that language is not being practiced enough by the learners.

With respect to Carlos, once more, experiential knowledge appears to have played a more influential role in shaping the trainee's practice. He seems to view teaching with a teacher-centered focus. From the first to the last of his reports, he emphasizes his doings, sayings and sensings in relation to the contents and materials of the lesson, as can be seen in ...consegui não deixar os alunos levantarem sem razão de suas cadeiras, aumentar a força da voz, tratar vários tópicos do conteúdo da aula 
com sucesso, e organizar um pouquinho mais o quadro. His reflections do not shift from this perspective to a learner-centered perspective, in which he would picture the learners as main participants or, at least, emphasize the effects of the lesson on the learners. In terms of acting, teacher and students do not act upon each other, as in ...os alunos tendo participado e respondido as perguntas extras (eles deram os pares de animais em inglês, e depois formularam sentencas segundo o modelo the cat eats the bird). In relation to sensings, he describes the learners as dependent upon his inducement for cognition to take place successfully, as in $A$ surpresa dos alunos frente a minha pergunta (mostrei o guarda-chuva para todos e perguntei whose umbrella is this?) tentando descobrir o dono do guarda-chuva, e o efeito da encenação levou os alunos a entenderem o significado do dito titulo. In reference to sayings, the students basically answer his questions and formulate sentences according to a given model, such as in ...formularam sentenças segundo o modelo the cat eats the bird. Finally, concerning being, he does not mention himself or the students qualifying anything.

Although the selection of participant roles in Daniel's reported practice shows him as a more dominant and central figure in the classroom - he acts, says, senses and is/has more than the students - I find him to be the only subject whose practice, from the viewpoint of ideational meanings, is influenced, to a large extent, by theoretical knowledge. The use of this knowledge may have helped him overcome traditional models of teaching as well as facilitated the internalization of communicative foreign language teaching principles. He worries about selecting topics and activities that have personal relevance to the learners, as in Nesta aula foi tratado o tema 'violência doméstica'. Acho que fomos felizes na escolha deste tema, pois a turma demonstrou muito interesse em debatê-lo e falar a respeito de suas experiências de vida, seu dia-a-dia, and to approach such topics and activities in ways that lead them to think about social matters of the world to which they belong, as demonstrated in the extract that follows.

Acho que tal tema me proporcionon a oportunidade de mostrar aos alunos o lado social e familiar das pessoas. Os pais abusando dos seus filhos, a violência urbana, a falta de respeito entre as pessoas. Todos estes exemplos são freqüentes na sociedade em que vivemos, são vistos com olhos passivos e habituados a tanta violência. Porém com pequenas atitudes 
podemos transformar o mundo em um lugar melhor para se viver e aqui entra a função social do professor, sua responsabilidade em educar seus alunos.

His reported practice shows that he finds teaching and learning modes of expression of values and beliefs, and not just forms of manifestation of information and knowledge.

The ideational findings suggest that the trainees perceive themselves as more powerful than the students. It is a fact that power relations are nearly always asymmetrical, especially considering the educational setting, where knowledge (a factor that influences unequal distribution of power) is not shared out equally between the teacher and the learners (WRIGHT, 1987). It seems though that, in order to fit new trends of teaching and learning (FREIRE, 1997; VYGOTSKY, 1987), teachers must try to leave such asymmetry out of sight by adopting a stance that does not picture them in a position of dominance and control so that learners feel more comfortable to undertake active roles in the classroom, such as the role of inquirers, initiators, investigators.

The literature surveyed in relation to the process of teaching/ learning (FREIRE, 1997; VYGOTSKY, 1987) - which forms the basis of recent theories - advises teachers no longer to play the role of transmitters of knowledge, worry solely about the content of lessons, maintain a high degree of control over the learners, or center the process of teaching/learning in themselves. Rather, teachers are advised to help learners to construct the knowledge, skills and strategies they need to facilitate their own development, thereby making them feel responsible for learning and helping them to become autonomous. Additionally, learners must be seen as partners and explorers in the process of teaching/learning. In this conception, teacher and learners share the responsibility of teaching/learning.

In pursuing the objective of this study in relation to interpersonal meanings, the analysis focuses on the 'whats' and 'hows' regarding aspects related to interaction, such as adequacy in the use of language, negotiation of meaning and teacher assistance to students.

A widespread premise underlying communicative methods of foreign language teaching is that it is an essentially interactive process. This notion is fundamentally grounded on social interactionist 
perspectives. For social interactionists, children are born into a social world, and learning occurs through interaction with other people (WILLIAMS; BURDEN, 1997; VYGOTSKY, 1987).

Another position adopted by interactionists is that in order to suit the capabilities of children when learning a language, adults ought to modify their speech. Caretaker talk is the term used to refer to this modified language used with children, which is characterized by a slower rate of speech, higher pitch, varied intonation, short and simple sentence patterns, frequent repetition and paraphrase.

Adopting this same interactive view of language learning to foreign language learning, theorists like Williams \& Burden (1997) state that interaction in the target language also plays a crucial role in the learning process. As for the use of modified language in foreign language teaching-learning, Krashen (1982) states that the input learners receive has to be made comprehensible. Long (1983) adds to Krashens' perspective saying that interactional modifications are a necessary mechanism for learning to take place, since, many times, it is the modified speech that makes input comprehensible, which, in turn, is what promotes learning. Such adjustments that speakers make to their speech in order to make input comprehensible, both in trying to understand others' utterances and in trying to make themselves understood, has been called in the literature negotiation of meaning.

The analysis of interpersonal meanings reveals that the trainees show incoherence in reporting to hold beliefs that their discursive practices fail to corroborate. It appears then that, also from this point of view, teachers tend to rely on experiential knowledge to a larger extent in contrast with theoretical knowledge.

Alice, in her representation of classroom realities, shows awareness of the importance of negotiation of meaning for interaction to take place. Yet, she does not negotiate meaning until the 5th lesson, as illustrated by the passage

Assim, adiantou muito pouco enriquecer o conteúdo da aula com palavras
'slow', 'fast rhythm', 'sad', 'lively style' pois eu não as negociei e os alunos
ficaram sem entender o que elas significavam. A nãa negociação de
significados em uma aula de língua estrangeira pode causar a impotência
do aluno perante o aprendizado e conseqüentemente desmotivação. 
As conveyed by her sayings, she does not attach due importance to negotiation of meaning. Her modalized discourse (highlighted in bold) seems to leave room for questioning whether she is convinced about the truth of her own proposition. Instead of negotiating meaning with her students, she repeatedly uses translation, as in Para tentar ajudá-los, perguntei qual era o problema com a atividade, eles, então, disseram que não conseguiam ler o texto, que o texto era difícil, e pediram a tradução. Entretanto, a tradução do texto em nada ajudou, os alunos continuaram sem saber resolver a atividade. In fact, along Alice's reports, she criticizes her several uses of translation in class, showing theoretical knowledge in relation to the principle that communicative methodologies hold regarding its use - not to be used, unless necessary. However, she persists on using translation throughout her teaching practice, as illustrated by another example:

\section{0 problema com esta atividade talvez já tenha ocorrido na leitura do enunciado, ao ler epedir a compreensão faltou pedirpara que eles dissessem com as suas palavras o que deveria ser feito e não a tradução, já que tradução não significa compreensão.}

In reading the extract above, one is tempted to believe that the trainee finds translation helpful. Nevertheless, although she is assertive when she states that translation does not imply understanding (underlined in the extract above), she modalizes (in bold) her discourse when saying that it is possible that the students' misunderstanding is due to failure to negotiate the meaning of the instructions given for the activity, instead of using translation.

Experiential knowledge, again, appears to be playing a crucial role in her practice. It is likely that her own experience in learning an FL was based on translation, not on meaning negotiation.

In the 6th and 7th lessons, however, she no longer uses translation and reports to have no problems with meaning negotiation anymore. At the same time, she points out that the students now succeed in the accomplishment of the activities proposed, as can be noticed in the following extract from the $6^{\text {th }}$ lesson: Em seguida distribui a atividade 13, a negociação de compreensão do enunciado foi bem conduzida e os alunos começaram a fazer a atividade. 
At this point, discursive change is apparent in her reports, signaling behavior change. It seems that her experience in the shoes of a teacher shows her that this communicative strategy fosters positive results. Her experiential knowledge is then re-fed by her new experience, causing underlying theoretical knowledge, already available, to be implemented as experiential knowledge. By this means, she incorporates this dimension in her practice.

Bento's reports devote great attention to that (in)adequacy of his speech to the learners' capacity. He comments in all his texts that his speech is not adequate to the students' English level of proficiency, as demonstrated in a self-criticism: A fala estava rápida para a capacidade de compreensão destes, alem de não calibrada, usei expressões de linguagem não trabalhadas com os alunos em sala. This categorical comment, regarding his first lesson, shows his acknowledgement of the mismatch between his speech and that of the students. His following comments, though, are less categorical, as instantiated in Tenho que calibrar minha fala. Me vejo utiliz̧ando expressões comuns ao nivel avançado. Isto não deve se tornar uma constante, pois os meus alunos estão apenas começando e o conhecimento ainda é básico.

The example above seems to demonstrate the trainee's willingness to modify his speech in order to suit the students' communicative competence. However, in spite of the statement of his intentions, he does not fulfil them.

In my interpretation, Bento is not committed to change his speech because of a feeling that a fast and elaborated mode of language use shows knowledge, and knowledge asymmetry is a powerful tool to impose power relations, dominance and control, and thus a way to enhance discipline in class, an aspect that worries him, as noticed in

O nervosismo, que é comum a qualquer estagiário em sua primeira aula, não foi tão grande como imaginava que seria. Ao meu ver, após pensar sobre o primeiro dia de estágio, cheguei a conclusão de que a maneira barreira que impus para evitar a indisciplina, o nervosismo e a situação do 'não saber o que fažer' foi: não dê espaço aos alunos, tome controle total, fazendo com que o inesperado não ocorra.

Experiential knowledge has certainly echoed more strongly. Based on this trainee's stance, it appears that the values and beliefs encoded in his discourse are grounded on traditional dimensions of 
hierarchy, in which occupations predefine the positions to be adopted by social participants. He appears to believe that hierarchy is directly related to power and that teachers have a superordinate position in relation to their learners.

Carlos makes few comments about interaction and negotiation of meaning in the FL classroom. He simply includes them in his reports as aspects to be improved. However, his feeling is conveyed by assertive sentences (not modalized) that seem to demonstrate his commitment to improve his practice. The example that follow illustrates this interpretation.

0 que bá de ser melhorado para futuras aulas é o acompanbamento de mimica e interpretação às explicações e novidade apresentadas aos alunos, para torná-las mais vivas, mais compreensiveis e evocativas e assim justificar o fato do professor falar o máximo possivel em inglês.

It appears, thus, that he has theoretical knowledge as to the importance of interaction in the FL classroom. Yet he probably still activates experiential knowledge when entering the classroom and is, thus, not able to accomplish such an important dimension for FL learning to occur. According to Ellis (1997), learning a language is a distinctively human social activity in which examples of its major features are interaction, collaboration and negotiation. If students are not involved in doing things, in speaking, in negotiating meaning, in expressing their feelings, in having responsibilities and in sharing experiences, the predisposition for learning, a result of a combination of the level and quality of the teacher and the learner's involvement in the day-by-day of the classroom, is likely to be disrupted.

Daniel's intrinsic models of foreign language teaching and learning seem to allow him to value interaction above all. He comments that he is pleased that students are interacting in class, although it may cause indiscipline, as in A turma começa a interagir mais nas correções. Isto me deixa contente, porém sei que a indisciplina também pode se tornar presente. His modalized discourse (in bold in the example) seems to demonstrate that he is not sure whether interaction causes misbehavior. This seems to picture him as having a more contemporary view of the classroom. What matters for him, it appears, is that students participate and communicate in the FL, even if that 'possibly' breaks up with the 
discipline for some time. It seems he would rather have interactive students developing their conversational competence than quiet ones who do not learn.

Still in relation to interaction, Daniel makes several mentions to his assistance to students as a means of checking their understanding. He does not picture himself as committed to assistance in the beginning of his teaching practicum, but the situation changes with time. In his first lesson, he states he 'tried' to assist the students; in the second, he assertively states that teacher assistance is helpful to students, but still pictures as a 'necessity' to make it constant in the ongoing process of his lessons; in the third, he is assertive in stating that he assists the students; and in the sixth, he already pictures his students assisting their colleagues, which makes him happy. His discursive change appears to demonstrate that he has developed as a teacher to the point of showing to his students that the FL classroom has to be characterized by collaboration.

Daniel, thus, appears to be the subject who mostly succeeded in integrating theory with practice, despite some traces of traditional pedagogy, as the transitivity analysis signals. My interpretation of this finding is that his "apprenticeship of observation" has not been such a hard burden to get rid of as it has been for the others. In this case, the knowledge he has internalized during his educational life has been more influenced by his experience and explicit inputs received in the shoes of a teacher-learner in a licenciatura course than in the shoes of a learner in childhood and adolescence, a supposition that goes against Williams \& Burden's (1997) contention that perceptions and beliefs about teaching seem to be well established by the time learners get to university. In fact, it is my belief that it is possible to overcome traditional models of teaching, but it needs constant effort (to reflect critically upon the teaching/learning process) and takes time. I would say that this is only possible when one is used to being critical, a stance that, unfortunately, is not often encouraged at school.

The results of the present study seem to corroborate the literature in that experiential knowledge plays a significant role in shaping teachers' practice. Alice's insistence on using translation and her resistance to negotiate meaning seems to me the best example to demonstrate the power that experiential knowledge exerts over teachers, who even having theoretical knowledge that is contrary to their experiential one, continue doing things they know, from a theoretical perspective, that are not effective to the ongoing development of learning a foreign 
language. Additionally, experiential knowledge, it seems, also exerts a powerful role in influencing teachers' assimilation of theoretical knowledge. It is as if one only assimilates some theory when it makes sense in the light of her/his experience. In Alice's case, she only incorporates the knowledge explicitly raised since her first report about negotiation of meaning when she feels, in class, that translation does not help her students in many situations.

Practice then appears to be mainly fed by prior experiential knowledge and to a lesser extent by theoretical knowledge, but during practice, this earlier experiential knowledge is further fed and thereby enriched by the new experience. By the same token, experiential knowledge is enriched with theoretical knowledge, which, in turn, is better assimilated when acquired in an experiential manner. It is such an integration of knowledge, rather than externally imposed knowledge alone or experiential knowledge alone, that is supposed to underpin each teacher's way of working (FREEMAN; JOHNSON, 1998; FLOWERDEW, 1998; BAILEY et al, 1996; FREEMAN, 1996a, 1996b). Teachers must have their practice grounded in theoretical and experiential knowledge together, a practice that appears to be more easily achieved with criticism and reflection, for values, which are culturally bound, take a long time to form, and once they are established, they tend to be resistant to change.

Summing up, the discursive analysis carried out regarding teachers' discourse agree with the contention that what teachers know about teaching is greatly influenced by their experience and the classrooms which they come from. As Freeman \& Johnson (1998, p. 401) state,

teachers are not empty vessels waiting to be filled with theoretical and pedagogical skills; they are individuals who enter teacher education programs with prior experiences, personal values, and beliefs that inform their knowledge about teaching and shape what they do in their classrooms.

Although it may seem that personal histories are likely to be replicated, conscious knowledge of these histories may help teachers to triumph over the leaning to unconsciously reproduce the actions, performance and conduct of others (BAILEY et al, 1996). If teachers, then, do not constantly reflect and evaluate their practice in the light of 
their values and beliefs as well as of theory and experience, they are likely to perpetuate intrinsic models acquired during their lives, even if sometimes not aware of that (FREEMAN; JOHNSON, 1998). Today's world is characterized by several changes and transformations and teachers cannot hold back from responding to these trends.

\section{References}

BAILEY, K. M.; BERGTHOLD, B.; BRAUNSTEIN, B.; FLEISCHMAN, M.P. H.; TUMAN, J.; WAISSBLUTH, X.; ZAMBO, L. The language learner's autobiography: Examining the apprenticeship of observation. In FREEMAN, D.; RICHARDS; J. (Eds.) Teacher learning in language teaching. Cambridge: Cambridge University Press, 1996. p. 11-29.

BAKHTIN, M. Marxismo e filosofia da linguagem. São Paulo: Hucitec, 1981.

CLARK, K. The linguistics of blame. In: JOHNS, Ann (Ed.) Language, text and context. Oxford: Oxford University Press, 1992.

ELLIS, R. Second language acquisition. Oxford: Oxford University Press, 1997.

FAIRCLOUGH, N. Discourse as social change. Cambridge: Polity Press, 1992.

Language and power. London: Longman, 1989.

FLOWERDEW, J. Language learning experience in L2 teacher education. Tesol Quarterly, v. 32, n. 3, p. 529-535, 1998.

FREEMAN, D. (1996a). To take them at their word: language data in the study of teachers' knowledge. Harvard Educational Review, v. 66, n. 4, p. 732-761, 1996a.

Renaming experience/reconstructing practice: Developing new understandings of teaching. In: FREEMAN, D.; RICHARDS, J. 
(Eds.) Teacher learning in language teaching. Cambridge: CUP, 1996b. p. 221-241.

; JOHNSON, K. Reconceptualizing the knowledge-base of teacher education. Tesol Quarterly, v. 32, n. 3, p. 397-418, 1998.

FREIRE, P. Pedagogia da autonomia. São Paulo: Paz e Terra, 1997.

GOLOMBEK, P. A study of language teachers' personal practical knowledge. Tesol Quarterly, v. 32, n. 3, p. 447-464, 1998.

HALLIDAY, M. A. K. An introduction to functional grammar. London: Edward Arnold, [1985] 1994.

KRASHEN, S. Principles and practice in second language acquisition. Oxford: Pergamon, 1982.

LARSEN-FREEMAN, D. Techniques and principles in language teaching. New York: OUP, 1986.

LONG, M. H. (1983). Native speaker/non-native speaker conversation in the second language classroom. In: CLARK, M. A.; HANDSCOMBES, J. (Eds.) Pacific perspectives on language learning and teaching. Washington D.C.: Tesol '82, 1983. p. 207-225.

MARTIN, J. R.; MATTHIESSEN, C.; PAINTER, C. Working with functional grammar. London: Arnold, 1997.

RICHARDS, J. C.; LOCKART, C. Reflective teaching in second language classrooms. Cambridge: CUP, 1996.

.; RODGERS, T. Approaches and methods in language teaching. New York: CUP, 1986

UR, P. A course in language teaching: practice and theory. Cambridge: CUP, 1996.

VAN PATTEN, B. How language teaching is constructed. The Modern Language Journal, v. 81, n. 1, p. 1-5, 1997. 
VYGOTSKY, L. S. Pensamento e linguagem. São Paulo: Martins Fontes, 1987.

WILLIAMS, M.; BURDEN, R. Psychology for language teachers. Cambridge: Cambridge University Press, 1997.

WRIGHT, T. Roles of teachers and learners. Oxford: Oxford University Press, 1987. 